\begin{tabular}{|c|c|c|}
\hline 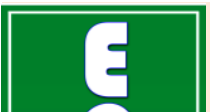 & $\begin{array}{l}\text { International Journal of Current Research in } \\
\text { Biosciences and Plant Biology }\end{array}$ & $m$ \\
\hline & Volume $7 \bullet$ Number 8 (August-2020) • ISSN: 2349-8080 (Online) & \\
\hline $\begin{array}{l}\text { EXCELLENT } \\
\text { PUBLISHERS }\end{array}$ & Journal homepage: $\underline{w w w . i j c r b p . c o m}$ & \\
\hline
\end{tabular}

\title{
Effect of Arka microbial consortium on growth and germination percentage of French bean and Amaranthus seeds
}

\author{
Priyadarshini Pillai*, M. Punitha, S. Ranjitha, R. Ragavi, G. Roopa, \\ Ramla and K. J. Sahana
}

Department of Botany, Jyoti Nivas College Autonomous, Bengaluru, Karnataka, India

*Corresponding author; e-mail: priya.pillaio7@gmail.com

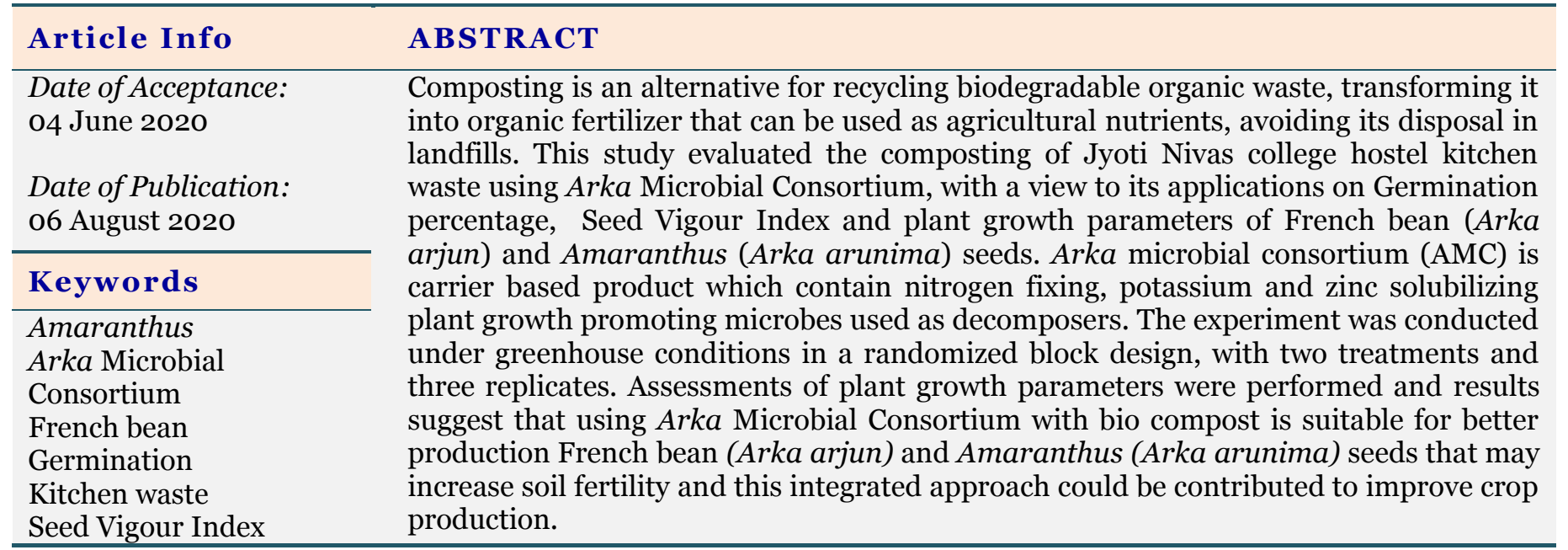

\section{Introduction}

The management of municipal solid wastes is a problem faced by all developing countries. The rapid pace of growth of population, economic activity, urbanization and industrialization is associated with accelerated waste generation (Srivastava et al., 2015; Kumar et al., 2017; ButuandMshelia, 2014). Therefore, inadequate waste management is a serious environmental problem, which is even more pronounced when it comes to biodegradable municipal solid wastes. Biodegradable solid wastes are usually incinerated (Agarwal et al., 2005; Taylan et al., 2008) or dumped in open areas, which may cause health and environmental issues. In addition, the incineration of biodegradable wastes with a high moisture content results in the release of dioxins (Katami et al., 2004), highly toxic and persistent pollutants that pose a threat to humans and the environment (Paritosh et al., 2017). In this context, there is a need to prioritize the management of biodegradable solid wastes, which can be undertaken by responsible governmental authorities as well as non-governmental entities (associations, cooperatives and companies).

Composting has several advantages over incineration and land filling, and it is an effective 
solution to recycle such wastes. This is because it has lower operating costs, reduces environmental impacts and, most importantly, the final product can be used as fertilizer (Li et al., 2013). This technique not only reduces the amount of waste sent to landfills, but also contributes to social, ecological and economic improvement, being the best alternative for the management and transformation of organic waste.

In India, there are highly populated urban areas where the production of a large amount of household compost which could be used as fertilizer in nearby agricultural fields would be possible (Vich et al., 2017). From a sustainability point of view, household organic waste must be efficiently reused in the economic and productive cycle before its final disposal (Ferreira et al., 2018).

Use of biocompost for vegetable production in large scale can solve the problem for disposal of wastes and also solve the lack of organic matter. Therefore, the main objectives of this present investigation were to evaluate the effect of different doses of biocompost with the combination of Arka Microbial Consortium on seed germination and growth parameters of French bean (Arka arjun) and Amaranthus (Arka arunima) seeds.

\section{Materials and methods}

\section{Sample collection}

Kitchen wastes were collected from Jyoti Nivas College girls hostels, Bengaluru in sterile polythene bag and the collected wastes were brought to laboratory immediately before indigenous decomposition

\section{Production of Bio compost}

For production of Bio compost, $20 \mathrm{~kg}$ kitchen waste was collected from Jyoti Nivas College hostel, Bengaluru and chopped into small pieces and pile method was followed (Rahman, 2009). Compost pile contained $20 \mathrm{~kg}$ of chopped kitchen waste, soil, $1 \mathrm{~kg}$ cocopeat and $20 \mathrm{ml}$ AMC (Arka Microbial Consortium) were used as an effective enhancer, which were collected from the Biotechnology and Microbiology laboratory, Indian Institute of Horticulture Research (IIHR), Bengaluru. The dimension of pile was approximately $60 \mathrm{~cm}$ (width) $\times 132 \mathrm{~cm}$ (length) $\times$ $60 \mathrm{~cm}$ (height). Soil, cocopeat, AMC and chopped kitchen waste arranged in different layers and finally covered with polythene sheet. Every seven days, the moisture content of the experiment was adjusted to $60 \%$ through the addition of water before and during the composting process continued. When the temperature in compost piles reached the ambient temperature, addition of water was stopped although the composting process continued. Each compost pile was manually mixed with a shovel for about 10 minutes to turn the pile and provide aeration. This was done every 15 days until the compost piles reached maturity. At $15^{\text {th }}$ day after turning the compost piles a 50 gm sub-samples was randomly collected from the compost pile and analyzed using some physical, biological and chemical parameters. After 15 days of composting, when the compost was matured, it was used to assay the effect of bio compost on growth and germination percentage of French bean (Arka arjun) and Amaranthus (Arka arunima) seeds.

\section{Experimental design}

An experiment was conducted at Botanical Garden, Jyoti Nivas College, Bengaluru during November 2019 to February 2020 to assay the effect of bio compost with the combination of Arka Microbial Consortium, on Germination percentage, Seed Vigour Index and plant growth parameters of $A r k a$ arjun (French bean) and Arka arunima (Amaranthus) seeds. The Botanical Garden was raised under 30 per cent shade net. The experiment was laid out in Completely Randomized block design 2x1 $\mathrm{m}$ size. Three replications were maintained for each treatment. The media comprised of soil, coco peat, bio compost and Arka microbial consortium with two treatment combinations and replicated thrice. The healthy seeds of Arka arunima-Amaranthus (Amaranthus tricolor L.) and Arka arjun -French bean, (Phaseolus vulgaris L.) were collected from the Agriculture Department of Indian Institute of Horticulture Research (IIHR) Bengaluru and sown in pots as per the treatment combinations. Three replicates were selected randomly for recording observations in each treatment and data were recorded on germination percentage, seed vigour Index, survival and other plant growth parameters at $15^{\text {th }}, 30^{\text {th }}, 60^{\text {th }}$ and $90^{\text {th }}$ days after seed sown. 
Germination percentage was calculated by number of germinated seeds divided by the total number of seeds sown in pots and multiplied by 100 . Germination period was calculated as the difference between initial and final emergence (number of days). For determination of seedling vigour index 5 seedlings were randomly selected from each pot and their individual shoot and root length were measured. The vigour of the seedlings was determined by following the formula of AbdulBaki and Anderson (1973). Vigor index $=$ [mean of root length $(\mathrm{cm})+$ mean of shoot length $(\mathrm{cm})] \times$ percentage of seed germinations.

\section{Data analysis}

The experiment was carried out following Randomized Block Design (RBD) with three replicates and 10 plants were used in each replicates. Data on plant growth parameters were recorded and statistically analyzed with the help of computer package program SPSS (SPSS Inc., Chicago, IL, USA) for DMRT test.

\section{Results and discussion}

The germination of French bean and Amaranthus seeds, and seedling parameters parameters as influenced by Arka Microbial Consortium (AMC) are presented in Tables $1-4$.

Table 1. Effect of biocompost with the use of Arka microbial consortium (AMC) on French bean (Arka arjun) seeds.

\begin{tabular}{llllll}
\hline $\begin{array}{l}\text { Treatment } \\
\text { (Days) }\end{array}$ & $\begin{array}{l}\text { Germination Period } \\
\text { (days) }\end{array}$ & $\begin{array}{l}\text { Germination } \\
\text { (\%) }\end{array}$ & $\begin{array}{l}\text { Shoot height } \\
\text { (cm) }\end{array}$ & $\begin{array}{l}\text { Root } \\
\text { length(cm) }\end{array}$ & $\begin{array}{l}\text { Vigour } \\
\text { Index }\end{array}$ \\
\hline 15 & 8 & 60 & 5.5 & 3.43 & 330 \\
30 & 8 & 70 & 5.85 & 3.49 & 409.5 \\
45 & 6 & 90 & 6.66 & 3.78 & 599.4 \\
60 & 6 & 90 & 7.11 & 3.88 & 639.9 \\
SEm $( \pm)$ & 0.25 & 0.4 & 0.16 & 0.8 & 0.26 \\
CD at 5\% & 0.76 & 1.23 & 0.47 & 2.42 & 0.78 \\
\hline
\end{tabular}

Table 2. Effect of biocompost ( without AMC) on French bean (Arka arjun ) seeds.

\begin{tabular}{llllll}
\hline $\begin{array}{l}\text { Treatment } \\
\text { (Days) }\end{array}$ & $\begin{array}{l}\text { Germination Period } \\
\text { (days) }\end{array}$ & $\begin{array}{l}\text { Germination } \\
\text { (\%) }\end{array}$ & $\begin{array}{l}\text { Shoot height } \\
\text { (cm) }\end{array}$ & $\begin{array}{l}\text { Root } \\
\text { length(cm) }\end{array}$ & $\begin{array}{l}\text { Vigour } \\
\text { Index }\end{array}$ \\
\hline 15 & 8 & 30 & 4.3 & 2.82 & 129 \\
30 & 8 & 60 & 4.66 & 2.87 & 279.6 \\
45 & 6 & 70 & 5.57 & 3.65 & 389.9 \\
60 & 6 & 70 & 5.71 & 3.74 & 399.7 \\
SEm $( \pm)$ & 1.23 & 0.87 & 0.21 & 0.31 & 0.64 \\
CD at 5\% & 3.73 & 2.65 & 0.63 & 0.9 & 1.84 \\
\hline
\end{tabular}

Table 3. Effect of biocompost with the use of Arka microbial consortium (AMC) on Amaranthus (Arka arunima) seeds.

\begin{tabular}{llllll}
\hline $\begin{array}{l}\text { Treatment } \\
\text { (Days) }\end{array}$ & $\begin{array}{l}\text { Germination } \\
\text { Period (days) }\end{array}$ & $\begin{array}{l}\text { Germination } \\
(\%)\end{array}$ & $\begin{array}{l}\text { Shoot Height } \\
\text { (cm) }\end{array}$ & $\begin{array}{l}\text { Root } \\
\text { length(cm) }\end{array}$ & $\begin{array}{l}\text { Vigour } \\
\text { Index }\end{array}$ \\
\hline 15 & 8 & 25 & 1.38 & 0.22 & 34.5 \\
30 & 8 & 50 & 1.62 & 0.26 & 81 \\
45 & 6 & 70 & 2 & 0.28 & 140 \\
60 & 6 & 80 & 2.48 & 0.3 & 198.4 \\
SEm $( \pm)$ & 0.31 & 0.64 & 0.1 & 0.1 & 0.23 \\
CD at 5\% & 0.9 & 1.23 & 0.27 & 0.15 & 0.73 \\
\hline
\end{tabular}


Table 4. Effect of biocompost (without AMC) on Amaranthus (Arka arunima) seeds.

\begin{tabular}{llllll}
\hline $\begin{array}{l}\text { Treatment } \\
\text { (Days) }\end{array}$ & $\begin{array}{l}\text { Germination } \\
\text { Period (days) }\end{array}$ & $\begin{array}{l}\text { Germinatio } \\
\text { n (\%) }\end{array}$ & $\begin{array}{l}\text { Shoot height } \\
\text { (cm) }\end{array}$ & $\begin{array}{l}\text { Root length } \\
\text { (cm) }\end{array}$ & $\begin{array}{l}\text { Vigour } \\
\text { Index }\end{array}$ \\
\hline 15 & 8 & 20 & 1.06 & 0.16 & 21.2 \\
30 & 8 & 35 & 1.16 & 0.16 & 40.6 \\
45 & 6 & 60 & 1.6 & 0.24 & 96 \\
60 & 6 & 70 & 1.8 & 0.26 & 126 \\
SEm $( \pm)$ & 1.18 & 0.89 & 0.36 & 0.41 & 0.57 \\
CD at 5\% & 2.87 & 2.71 & 0.77 & 0.8 & 1.34 \\
\hline
\end{tabular}

Germination percentage and Vigour Index was highest in French bean (Arka arjun) at $60^{\text {th }}$ day and lowest at $15^{\text {th }}$ day with the use of Arka microbial consortium (AMC). Similar results have been reported in Amaranthus (Arka arunima) seeds. Results indicated that use of Bio compost along with Microbial consortium in the medium used for seedling raising in French bean and Amaranthus seedlings had a great effect on the germination percentage of seeds and the consequent growth and development, due to favorable soil physical environment created by the addition of Arka Microbial consortium. Moisture content of seed or growth media is one of the important external factors affecting seed germination. In a similar study Rahman et al. (2010) found that application of Trichoderma compost with NPK fertilizers significantly increased the germination percentages and vigour index of chili.

The shoot and root length significantly increased in French bean and Amaranthus seeds, it was highest at $60^{\text {th }}$ day and lowest at $15^{\text {th }}$ day of treatment with AMC. These increases might be related to the positive effect of compost and microorganisms in increasing the root surface are per unit of soil volume, water-use efficiency and photosynthetic activity, which directly affects the physiological processes and utilization of carbohydrates. These suggestions are confirmed by analysis of biocompost which illustrates the higher levels nutrients and organic matter was in compost. Similar results were obtained by Zaied et al. (2003) on wheat. Rykobst et al. (1993) noted that application of S with NPK increased tuber yield of potato. Abdelaziz et al. (2007) reported that application of compost and microorganisms could replace conventional NPK fertilizers in the cultivation of rosemary (Rosmarinus officinalis), and consequently minimize environmental pollution by these compounds. Bongkyoon (2004) mentioned that the application of NPK and vermicompost showed an increment in the average tuber weight per plant.

This pointed out that the treatments without Arka microbial consortium recorded less values for all the parameters and among the Arka microbial consortium treatments, the values for all parameters were increased with increase in levels of Arka microbial consortium. These results can be attributed to a reason that production of plant growth promoting substances by plant growthpromoting microbes which were known to cause enhanced cell division and root development higher nitrogen fixation by nitrogen fixing bacteria, phosphorous and zinc solubilization by phosphorous solubilizing bacterium and zinc solubilizing bacteria respectively was responsible for early germination, healthy and quality seedlings. The present study was also supported by the findings of Sarvanan et al. (2012) in Casuarina equisetifolia seedlings (Shenoy and Kalagudi, 2002) and Jayashree et al. (2016).

\section{Conclusion}

From the above findings, it can be concluded that the compost produced by Arka microbial consortium and kitchen waste has high nutrient values which can be used effectively as bio compost or soil amended and this compost also can reduce the application of organic fertilizer. Arka microbial consortium comprises of different microbial strains which were perform different functions like early germination, Seedlings become ready for early transplantation by 5-7 days, increased seed vigour and high survival percentage in main field can be used to treat Arka microbial consortium to produce quality French bean and Amaranthus seedlings raised in protrays. 


\section{Conflict of interest statement}

Authors declare that they have no conflict of interest.

\section{Acknowledgement}

The authors express their profound gratitude to Dr. Sr. Elizabeth C S, Principal and Dr. Geeja S. Kurian Head of the Department, Department of Botany, Jyoti Nivas College Autonomous, Bengaluru, Karnataka (India).

\section{References}

Abdelaziz, M., Pokluda, R., Adelwahab, M., 2007. Influence of compost, microorganisms and NPK fertilizer upon growth, chemical composition and essential production of Rosmarinus officinalis L. Not. Bot. Hort. Agrobot. Cluj. 35, 1.

Abdul-Baki, A., Anderson, J. D., 1973. Vigour determination of soybean seed by multiple criteria. Crop. Sci. 3, 630-633.

Agarwal, A., Singhmar, A., Kulshestha, M., Mittal, A. K., 2005. Municipal solid waste recycling and associated markets in Delhi, India. Resour. Conserv. Recycl. 44, 73-90.

Bongkyoon, K., 2004. Effect of vermicompost on growth of fall-cropping potato in volcanic ash soil. Korean J. Crop. Sci. 49(4), 305-308.

Butu, A. W., Mshelia, S. S., 2014. Municipal solid waste disposal and environmental issues in Kano metropolis, Nigéria. British J. Environ. Sci. 2, 10-26.

Ferreira, A. K. C., Dias, N. S., Sousa Junior, F. S., Ferreira, D. A. C., Fernandes, C. S., Lucas, L. E. F. et al., 2018. Physicochemical and microbiological properties and humic substances of composts produced with food residues. J. Agric. Sci. 10, 180-189.

Jayashree, C., Jagadeesh, K. S., 2016. Nursery inoculation of the selected vegetable seedlings with a microbial consortium and its field performance in brinjal (Solanum melongena L.). M.Sc., Thesis, Univ. Agric. Sci., Dharwad.

Katami, T., Yasuhara, A., Shibamoto, T., 2004. Formation of dioxins from incineration of foods found in domestic garbage. Environ. Sci. Technol. 38, 1062-1065.

Kumar, S., Sith, S. R., Fowler, G., Velis, C., Kumar, J., Arya, S. et al., 2017. Challenges and opportunities associated with waste management in India. Royal Soc. Open Sci. 4, 1-11.

Li, Z., Lu, H., Ren, L., He, L., 2013. Experimental and modelling approaches for food waste composting. Chemosphere 93, 1247-1257.

Nzanza, B., Diana, M., Puffy, S., 2011. Tomato (Solanum lycopersicum L.) seedling growth and development as influenced by Trichoderma harzianum and arbuscular mycorrhizal fungi. Afr. J. Microbiol. Res. 5, 425-431.

Paritosh, K., Kushwaha, S. K., Yadav, M., Pareek, N., Chawade, A., Vivekanand, V., 2017. Food Waste to energy: An overview of sustainable approaches for food waste management and nutrient recycling. BioMed Res. Int. 19 p.

Rahman, M. A., Begum, M. F., Alam, M. F., Mahmud, H., Khalequzzaman, K. M., 2010. Effect of Tricho-compost, compost and NPK fertilizers on growth, yield and yield components of chili. Int. J. Sustain. Agril. Tech. 6(3), 64-72.

Rahman, M. A., 2009. Screening of Trichoderma spp. and their efficacy as a bio-conversion agent of municipal solid waste through appropriate technique of solid state fermentation. PhD thesis, Department of Botany, University of Rajshahi, Rajshahi-6205, Bangladesh.

Rykobst, K. A., Christiansen, N. W., Maxwell, J., 1993. Fertilization of russet Burbank in shortseason environment. Amer. Potato J. 79(10), 690-710.

Sarvanan, T. S., Rajendran, K., Santhaguru, K., 2012. Selection of suitable bio-fertilizer for production of quality seedling of Casurina equisetifolia using decomposed coir pith compost in Root Trainers. Asian J. Exptl. Biol. Sci. 3(4), 752-761.

Shenoy, V. V., Kalagudi, G. M., 2002. Plant host mediated enhancement of phosphorus use efficiency. In: Nat. Symp. on Mineral Phosphate Solubilization- 2002 (A. R. Alagawadi et al., Eds.), Univ. Agric. Sci., Dharward, pp. 11-12.

Srivastava, V., Ismail, S. A., Singh, P., Singh, R. P., 2015. Urban solid waste management in the developing world with emphasis on India: Challenges and opportunities. Rev. Environ. Sci. Bio Technol. 14, 317-337.

Taylan, V., Dayiha, R. P., Sreekrishnan, T. R., 
2008. State of municipal solid waste management in Delhi, the capital of India. Waste Manage. 28, 1276-1287.

Vich, D. V., Miyamoto, H. P., Queiroz, L. M., Zanta, V. M., 2017. Household food-waste composting using a small-scale composter. Rev. Ambien. Água. 12, 718-729.

Waghmode, M. S., Gunjal, A. B., Nawani, N. N., Patil, N. N., 2016. Management of floral waste by conversion to value added products and their other applications. Waste Biomass Valor. 9, 33-43.

Zaied, K. A., Abdelhady, A. H., Aida, H. A., Nassef, M. A., 2003. Yield and nitrogen assimilation of winter wheat inoculated with new recombinant inoculants of rhizobacteria. Pak. J. Biol. Sci. 6, 344-358.

\section{How to cite this article:}

Priyadarshini, P., Punitha, M., Ranjitha, S., Ragavi, R., Roopa, G., Ramla, Sahana, K.J., 2020. Effect of Arka microbial consortium on growth and germination percentage of French bean and Amaranthus seeds. Int. J. Curr. Res. Biosci. Plant Biol. 7(8), 16-21. doi: https://doi.org/10.20546/ijcrbp.2020.708.002 